\title{
LATE NORTH-AFRICAN SIGILLATA LAMPS: CURATORSHIP OF MUSEUM COLLECTIONS AND ARCHAEOLOGICAL RESEARCH
}

Maria Isabel D’Agostino Fleming1

\begin{abstract}
The Late African North African lamps of Terra Sigillata (African Red Slip Ware-ARS) are a category of objects which, alongside tableware, have acquired particular importance, not only for the volume of their production, but for their economic and commercial, iconographic and historical-religious implications. This article aims to present the development of fundamental research for the knowledge about the production and circulation of the ARS and in particular the lamps, taking as examples rich dialogues between the curatorial studies of museological collections and archaeological research that point the limits of the classical models of study of African ceramics and perform accurate reviews of dates, origins and contents of vessels, especially with archaeometric methods.
\end{abstract}

\section{Keywords}

North African lamps (ARS); Museum collections; Archaeological research; Production; Circulation; Rome.

\footnotetext{
1 Assistant Professor, University of São Paulo, São Paulo, Brazil. E-mail: mabelfleming@gmail.com
} 


\section{Resumo}

As lucernas norte-africanas tardias de Terra Sigillata (African Red Slip Ware-ARS) formam uma categoria de objetos que, ao lado das vasilhas de mesa, adquiriram uma importância particular, não só pelo volume de sua produção, mas pelas suas implicações econômicas e comerciais, iconográficas e histórico-religiosas. Este artigo tem como objetivo apresentar o desenvolvimento de pesquisas fundamentais para $o$ conhecimento sobre a produção e circulação da ARS e em particular as lucernas, tomando como exemplos diálogos profícuos entre os estudos curatoriais de coleções museológicas e pesquisas arqueológicas que apontam os limites dos modelos clássicos de estudo da cerâmica africana e realizam revisões acuradas de datações, origens e conteúdos das vasilhas, especialmente com métodos arqueométricos.

\section{Palavras-chave}

Lucernas norte-africanas (ARS); Coleções museológicas; Pesquisas arqueológicas; Produção; Circulação; Roma. 
Late North African sigillata lamps (African Red Slip Ware-ARS) is a category of objects that, alongside tableware, have acquired particular importance, not only for the volume of their production, but for their economic and commercial, iconographic and historical-religious implications. More recently, a set of studies of museum collections and archaeological research has brought new perspectives to the analysis of the role played by these objects in the Mediterranean context, having as a constant reference the vessels to which, with very few exceptions, were linked, whether in the field of production, that is, in the set of workshops in the central and northern North African regions, whether in circulation and distribution to the consumer centers.

In the case of museum collections, it is worth mentioning the herculean work of Mariarosaria Barbera and Roberto Petriaggi, Museo Nazionale Romano - Le Lucerne Tardo-Antiche di Produzione Africana (1993), which established an extremely detailed typology of the forms and decorative motifs of late North African lamps, in a sample of 305 pieces that compose the first catalog of the collection and represent a set of more than eleven thousand objects. This curatorial work of a material without contextualization, coming from large excavations, more specifically earthworks, carried out in Rome in the post-unification decades of Italy in the 19th century, is an exceptional example of the scientific exploitation of museum collections. The results allowed for the revision and reformulation of the typology of the Atlante delle forme ceramiche, I, Ceramica fine romana nel Bacino mediterraneo (medio e tardo impero) (Carandini et al., 1981). In this sense, the established typology is a mandatory reference for the great experts in ARS, among whom the main one is Michel Bonifay, Centre Camille Julien (Aix-Marseille Université / CNRS) (Bonifay, 2003, 2004, 2005a, 2005b, 2007, 2011, 2013, 2014, Bonifay et al., 2013, Bonifay and Tchernia, 2012, Capelli and Bonifay, 2014).

\section{Production and consumption - internal and external markets}

Among the issues relating to the production and consumption of late North African lamps, one must consider the problem of differentiated markets in the internal, central and northern regions of Tunisia, and the Mediterranean sphere. African food products, such as wheat, olive oil, wine and pickles of fish, salsamenta, garum, are the possible references associated with the diffusion of the lamps and the ARS and in the case of domestic or export destination, the workshops in which they were made were different. One of the domestic consumer products, such as olive oil, was shipped in bottles or barrels, lighter containers for land 
transportation, and could be accompanied by ceramic shipments to the coast. For export, it was packed in amphorae. However, in the Mediterranean, the spread of the ARS as a rule seems to be completely disconnected from the trade in amphorae and, rather, linked to the cereal trade, in this case wheat (Clay, 1992: 353; Panella, 1993: 639 apud Bonifay 2005 , p. 576, note 72 ) at least until the Vandal conquest. The association of wheat with the trade and diffusion of lamps and ARS can be traced from a long-term perspective concerning consumer sites in the West and East. According to Bonifay and Tchernia (2012: 328):

\begin{abstract}
Preceded, since the first half of the first century, for the non-negligible arrivals of African culinary ceramics, not only to Rome but also to Spain (Aguarod Otal 1991: 239), the onset of African imports into the West is very rapid. These imports reached their peak since the beginning of the second century (Fentress et al., 2004: Figure 11.3), which is in harmony with what we know about the evolution of imports of African wheat in Rome. In contrast, the beginning is slower in the East, where we must wait until the middle of the third century to obtain equivalent figures (Bes 2007: Fig. 2). One cannot explain the fall in imports in the Mediterranean during the second half of the third century and at the beginning of the fourth century (Fentress et al., 2004: 149; Bes 2007: 191): the chronological tools used may be involved Fentress et al., 2004: 148), but they probably only exaggerate a possible production crisis and also some changes in the ways of commercialization. More significant, no doubt, but also so difficult to explain, is the second fall of imports in the fifth century. All accounts seem to indicate that it begins well before the Vandal conquest (Fentress et al., 2004: 149, Bes 2007: 193). However, although other causes may be invoked, as a decline in population (and therefore consumption) in Rome and other cities around 400 AD (Zanini, 1996: 682 and Fig. 9), it is perhaps excessive to want to deny all effect of what was for the Empire one of the greatest catastrophes of the century: the political and then economic loss of the African territories. Then the chronological assessment of typologies may be involved.
\end{abstract}

Also in the issue of the diffusion / importation of lamps and ARS associated predominantly with the supply of wheat to Rome and provinces, the crosses of data and typologies presented by collections surveys (Carandini et al., 1981; Barbera and Petriaggi, 1993) and systematic excavations of archaeological sites provided interesting perspectives on the paths navigated by vessels. Such studies have as essential reference the practical, strategic and economic question of the flow of the ships in both directions of the route that they executed, in order to guarantee that they were always loaded. Considering the markets and the destination of the African ceramics, some hypotheses are proposed about the possible routes executed (Bonifay and Tchernia, 2012: 326 and Fig. 16.5). The studies suggest direct lines especially for Rome in view of the importance of trafficking. However, these direct-line routes were not intended for supplying the city from Carthage, according to references to a ship directly connecting Ostia from Hipona (Hippo Regius) 
(Digest 14.2.6). These routes also formed the indirect lines, taking into account the role played by the returning cargoes to Africa. Fentress et al., 2004 (apud Bonifay and Tchernia 2012: 326) suggested that Rome could have played a role as a port-warehouse between Africa and Sicily, a part of the island's supply in ARS would be secured by trade ships returning from Rome to Africa. In the same way, it was suggested that Alexandria was fed by ARS from the anona's return shipments (Bes, 2007: 190, apud Bonifay and Tchernia, 2012: 326). An extension of this model can be proposed considering the natural conditions related to the regime of the prevailing winds that make impossible the passage Alexandria-Roma along the coast of Cyrenaica from June. In that case, it would be advisable to first sail in the direction of Cyprus to the north-east and then reach Lycia and finally take a turn towards Rhodes and south of Crete (Arnaud, 2005: 13, apud Bonifay and Tchernia, 2012: 326). Thus, a lamp or vessel of ARS present in Crete could have traveled first of Africa to Rome, after Rome to Alexandria towards the Aegean Sea due to the opportunities of the departures of the ships and the seasonal regime of the winds. Finally, cabotage complements the form of redistribution of goods from the main ports, it has a well-known role and can sometimes ensure the primary diffusion of products. For ARS, the case of southwestern Sicily seems to be very important because of the proximity of the African coasts (Fentress et al., 2004, apud Bonifay and Tchernia 2012: 326). Numidia and Caesarian Mauretania, southern Sardinia and Cyrenaica could also, by reason of proximity, follow this regime of random diffusion of African ceramics (Bes, 2007, apud Bonifay and Tchernia 2012: 326). (Figure 1)

\section{Typology and production centers of late ARS lamps}

The main production centers were in Central Tunisia (Bizacena) and Northern (Zeugitana). The close association between the ARS and the lamps is established by investigations of the level of dependence of the latter on the former with reference to the decorative motifs. A systematic study, on the one hand, has observed the connections between the shapes and types of lamps in which the same decorative motifs appear and, on the other hand, their relation to the somewhat analogous adornments found in the African sigillata vessels. This qualitative leap in the research carried out by Barbera and Petriaggi (1993) made possible an unprecedented amount of information in two decisive fields: the chronology of decorations - which in turn is reflected in the dating of isolated types or copies - and the association between lamp production and vascular production in ARS. 




Fig. 1. Amphorae and African sigillata diffusion models: 1. heterogeneous African / Hispanic cargoes; 2. Cartago-Roma direct line; 3. return shipments to Alexandria and extensions; 4. cabotage of the Strait of Sicily. Source: modified from Bonifay and Chernia (2012: Fig. 16.5).

In terms of the desirable interaction between searches of collections with decontextualized material and archaeological excavations with material of known context, it was possible to verify that the beginning of the manufacture and the duration of the use of the main lamp productions in ARS proposed by Barbera and Petriaggi (1993) were confirmed by stratigraphic surveys of some of the major excavations of the 1970s-1980s in Carthage, one of the main production centers for ARS lamps. However, the near-exhaustion of the import of lamps by Rome, the so-called "classical Africans" (type Atlante, Form X) after the middle of the VI century $\mathrm{AD}$, is an information that emerges from the study of the decorative motifs of the collection of the Museo Nazionale Romano, which served as support for other important publications on the distribution of late African lamps in the African production centers of Central and Northern Tunisia. The study of Bonifay (2005b) was based on excavations of a used urban necropolis of the II to IV centuries in Pupput (Hammamet); three Christian basilicas of the V to VII centuries, in Sidi Jdidi (Aradi), and a fish salting factory, with continuous stratigraphy of the Ist to VII centuries, in Nabeul (Neapolis). The sites of Pupput and Nabeul are situated on the coast of Northern Tunisia and Sidi Jdidi is a few kilometers inland in the same region. Bonifay $(2005 \mathrm{~b})$ presents the 
typology of the African lamps of the II to VII centuries and has a section dedicated specifically to late itens of African sigillata of Atlante $X$ type, whose proposal is the distribution in two large groups according to the style of the decorations: one affiliated with sigillata $C$, from the center of Tunisia and the other affiliated with sigillata D, in northern Tunisia (Figures 2 and 3). On the other hand, the analysis of the collection of the Museo Nazionale Romano carried forward the hypotheses about the production areas of the lamps in ARS, that is, of the two main branches where production is divided. These branches comprise almost all the exported specimens, which are series 4 (type Atlante, Form VIII - also included in the set of types analyzed by Bonfay 2005b) and 6 (type Atlante, Form X).

It is indeed in the field of detection of manufacturing centers that the aforementioned confrontation between the decorative motifs of the lamps and those of the ARS vessels has produced the most innovative results. The observations of Barbera and Petriaggi (1993) made it possible to establish that the series 4 decorations, in their absolute majority, have no parallels with the vascular decorations and that, however, in a limited number of cases it is possible to go back to a possible common inspiration. These exceptions made it possible to place three specimens in the decorative repertoire of the various vascular productions of African sigillata C, located in Central Tunisia and five specimens of African sigillata D, whose area of origin is Northern Tunisia. As for its diffusion, the series 4 copies are present throughout the coastal area of the western Mediterranean, in Egypt and in the former Yugoslavia. This small set of lamps, whose hypotheses of its manufacturing centers were vague, began to fill a scientific gap. The difficulty so far encountered by scholars in geographically placing this production is, however, at least partly explained by the strangeness of much of the ornamental patrimony of the series 4 lamps in relation to the vascular. 


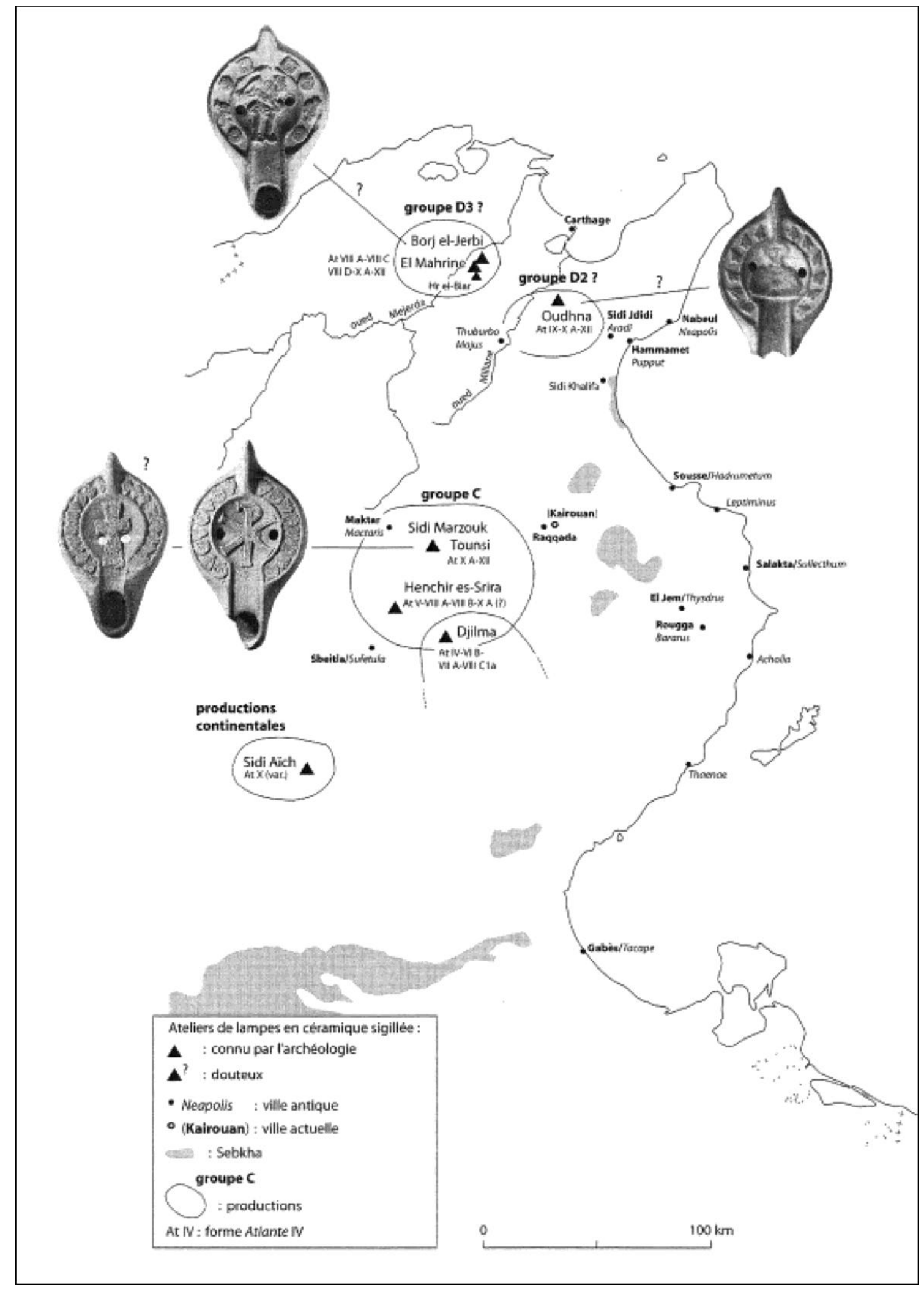

Fig. 2. Late lights in African sigillata (type Atlante X): proposition of location of the different groups of production. Source: Bonifay, 2005b: Fig. 5. 


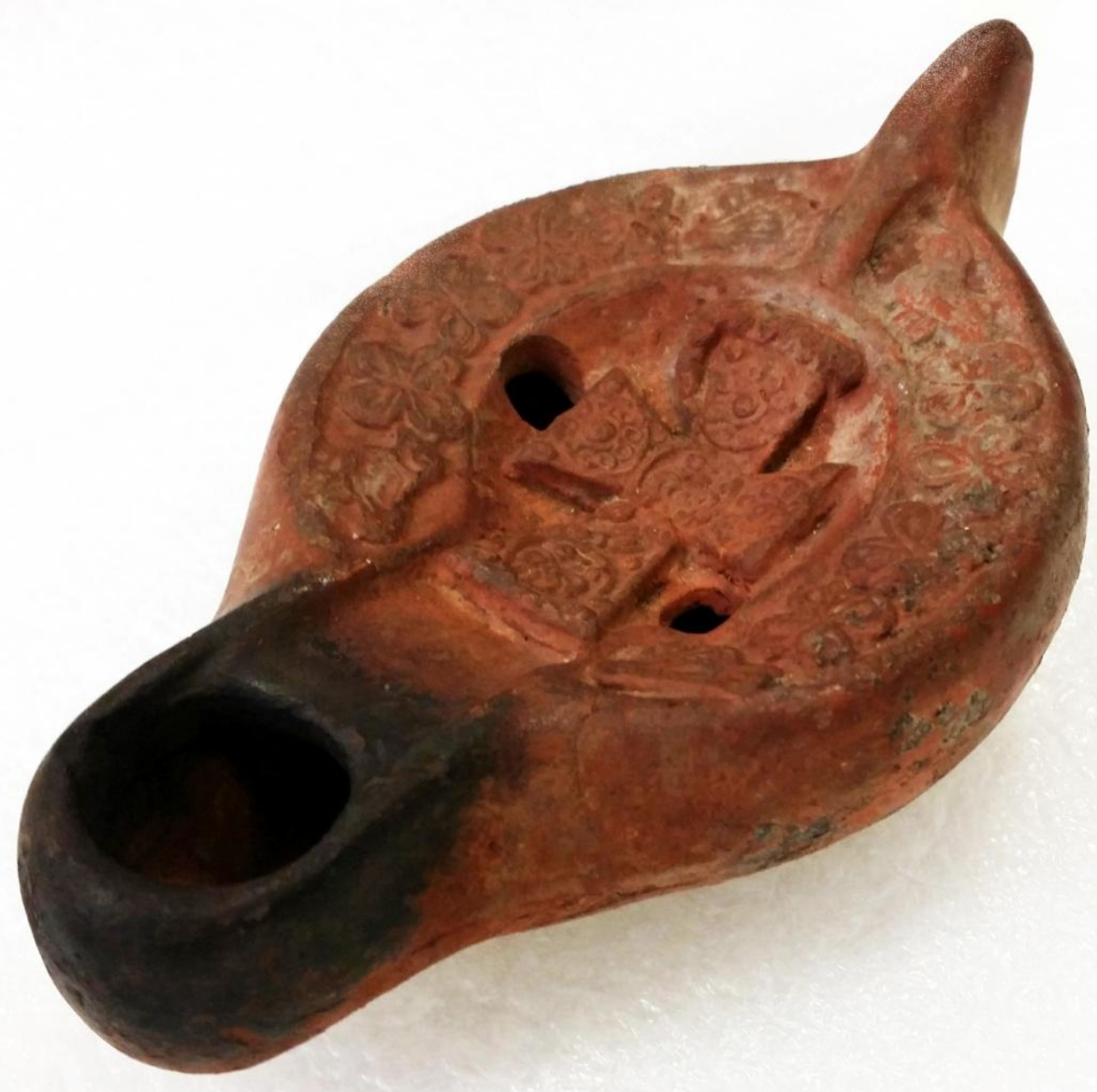

Fig. 3. Later Lucerne of African sigillata, V-VII centuries. Collection Museum of Archaeology and Ethnology-USP.

As for the analysis of the series 6 (type Atlante, Form X) lamps of the Museo Nazionale Romano, these, in fact, present much more confrontations with the documented decorations in the ARS vessels, even if an autonomous decorative area is identified in relation to of vessels. Such confrontations are often not limited to a generic resemblance, but they are direct and accurate. The parallels with the production of Central (Bizacena) and Northern (Zeugitana) Tunisia made it possible to confirm and clarify some of Hayes' intuitions (1972: 312), notably extending the reach (Barbera and Petriaggi, 1993: 8). There was a rich variety of relationships with the various productions of the African sigillata $\mathrm{C}$ of Central Tunisia, with different techniques of decoration and the African sigillata D of northern Tunisia, decorated with mold. The circulation of the so-called "classical Africans" has reached the entire Mediterranean basin, even though it must be pointed out that the enormous and capillary diffusion in the western regions, especially along the Italian coasts, finds no analogous parallel in the eastern area. 


\section{Lamps and ARS vases - production in independent workshops}

The authors propose an interesting hypothesis from the point of view of production centers (Barbera and Petriaggi, 1993: 424) and the separation of the production of vessels and lamps in independent workshops: the two large series do not seem to be attributable to two distinct and separated areas. On the contrary, both would have had relations with either the production of vascular ceramics located in Central Tunisia or with the corresponding one in Northern Tunisia. For the lamps series 4 the connections with the vessels produced in the two areas, however, would only be placed on the plane of a generic revival of iconography and decorative styles. In fact, the decorative motifs are much less careful and executed in a more rushed and approachable way. It seems, in short, that these lamps can be attributed to workshops specialized in this class of ceramics, but marginal in relation to the great productive and commercial circuits. The classic lamps, however, in a small number of cases can be attributed to the same vessels workshops in ARS, but appear to be episodes rather than rule. The assertion of the separation of workshops from vases and lamps is supported by the fact that a finding, hitherto unique, with a brief preliminary note on the Mahrine's workshop (Mackensen 1985: 29, apud Barbera and Petriaggi 1993: 425) in the interior of Carthage, gives details of the styles of the vessels and their specific forms and as for the lamps, it only mentions the existence of "Hayes types I and II". "From the article it is not possible to understand to which among the numerous types that make up the series 4 - the author refers: in fact, to such series corresponding to the Hayes type, also belong types with smooth disks or decorated with simple geometric motifs. Moreover, Mackensen remains vague also regarding the percentage of types 4 in relation to classical African and the vessels" (Barbera and Petriaggi, 1993: note 8). Regarding the relationship between series 4 and 6, the authors broadly propose that workshops that produced series 4 lamps with figurative decoration on the disc and lamps of the 6 series did not produce vessels in ARS.

The evident qualitative difference between the two series can be explained within the same workshop, considering different productions because of different costs, and not due to the use of more refined artisans for the series 6 . The authors propose that in the long period of coexistence between series 4 and the classic African, from the first quarter of the $\mathrm{V}$ century to the middle of the VI century, the production of lamps was probably carried out in three different and complementary types of workshops (Barbera and Petriaggi, 1993: 425): 
A - secondary workshops, marginal in relation to local economic centers;

B - workshops of intermediate importance, which mimic the iconographic models of vascular production in ARS;

C- main workshops, which mainly produce vases and, secondarily, lamps in ARS.

The first group of workshops can be attributed to the series 4 lamps, in particular the most distant from vascular confrontations, which are generally of rather modest quality. To the second group could be attributed the best among the exemplars of series 4 and the least cared among the classic Africans. As for the relationship with the vessels in ARS, while it seems almost certain to exclude it from the production of the workshops of the first group, some doubts remain in merit to the other two groups. In fact, the analysis of the decorative motifs makes it possible to hypothesize that type B workshops would revolve around series 4 and 6 lamps, but not of ARS vessels, and that type $C$ workshops would produce vases and lamps only from the series 6 , not series 4 .

The hypothesis raised by Barbera and Petriaggi awaits confirmations so that the discussions can proceed.

\section{Final considerations}

Later ARS vessels, including the lamps in this category, had Rome as the main market, confirmed by two types of sources. On the one hand, archaeological evidence of excavations, or better defining, finds, dating back to the eighteenth and nineteenth centuries, above all, fruits of a conception of the relationship with the ancient one marked essentially by collectionism, sporadic collection of materials that appeared on the surface, excavation practice completely ignorant of the existence of stratigraphy. On the other hand, more recent studies, dedicated to the investigation of networks of the Mediterranean trade (Arnaud, 2005, Bonifay and Chernia, 2012, Clay, 1992). However, if in current times they are the object of systematic excavations, vessels and lamps were mostly brought to light by urban works carried out in the post-unification period of Italy, quite adverse conditions that prevented their contextualization. In quantitative terms, a bold parallel can be made with Monte Testaccio, which maintains ordered strata of fragments of predominantly Dressel 20-type broken amphorae from Betica, with tituli picti, and in smaller numbers of two types of amphorae from Tripolitana, Libya, and Bizacena, Tunisia. In qualitative terms, however, instead of the 
information that can be extracted from the amphorae, ARS vessels and lamps were objects of unknown origin or had extremely generic inventory data from the various regions of Rome. In an exceptional volume they were literally referred to the museums of Rome. The scenario faced by researchers and the technical and scientific staff of museums is to live a phase in the history of archeology that is always marked by stratigraphic sensitivity and, at the same time, has to do with one of the legacies of archeology of the past decades. The extraordinary importance of the collection of the Museo Nazionale Romano, in this text analyzed, however, is not only due to its amplitude. The role of the capital of the ancient world played by Rome from the late Republic, as the point of arrival of commerce, especially maritime, from any point in the Empire is reflected in the composition of the collection, which ends up as a kind of representative sampling, almost without exception, of the entire panorama of typologies and productions that followed in the Mediterranean basin from the middle of the Roman Republic to the end of antiquity (Pavolini 1993: 3). The researches of museological collections have taken special force since the 1970s and 1980s and have resulted in systematic catalogs of great importance, such as the Atlante delle forme ceramiche, I, Ceramica fine romana nel Bacino mediterraneo (medio e tardo impero) (Carandini et al., 1981) The work undertaken with these collections involves studying and understanding the historical and cultural reasons that led to this form of formation, which is no longer acceptable, of most of the archaeological collections and, above all, to assign to the scientific duty to solve the problems in with current standards, creating appropriate criteria for study and publication.

In recent times, studies on the production, dating and distribution of ceramics and lamps in ARS go through numerous discussions and reviews of the main Mediterranean ceramic assemblies, with a view to solving problems of typology and chronology beyond the attribution of the location of the production centers. Is ample the scenery of the researches that call attention to the limits of the classical models of study of the African ceramic and perform accurate reviews of dating, origin and content of the vessels, especially with archaeometric methods (Capelli, Bonifay, 2014; Cau et al., 2012). On the other hand, the most important consumer market of the Empire has kept in its museums the main testimonies of this movement that involved practically all the provinces and in a period of at least nine centuries. The work done with ARS's lamp collection at Museo Nazionale Romano confirms that this fact could not be ignored and made possible the integration of its collection with those of well-defined contexts of North African producing centers, at the same time that it served of typological and chronological reference for the most 
advanced researches on late north-African sigillata ceramic. It is, therefore, an example of the dialogue between complementary forms of research essential to the development of the scientific knowledge in which the two parties win.

\section{Bibliography}

AGUAROD OTAL, C. Cerámica romana importada de cocina em la Tarraconense. Saragosse: Institución Fernando el Católico, 1991. Apud (Bonifay e Tchernia, 2012: 328.

ARNAUD, P. Les routes de la navigation antique. Itinéraires en Méditerranée. Paris: Errance, 2005. Apud Bonifay e Tchernia 2012: 326.

BARBERA, Mariarosaria; PETRIAGGI, Roberto Museo Nazionale Romano Le Lucerne Tard-Antiche di produzione Africana. Roma: Istituto Poligrafico e Zecca dello Stato, 1993.

BES, P. A Geographical and Chronological Study of the Distribution and Consumption of Tablewares in the Roman East. Leuven: Katolieke Universiteit Leuven, thèse de doctorat, 2007. Apud Bonifay e Tchernia, 2012: 328 .

BONIFAY, Michel. La céramique africaine, un indice du développement économique? AnTar, 2003, 11: 113-128.

BONIFAY, Michel. Études sur la céramiqueromaine tardive d'Afrique, BAE Int. Ser. 1301. Oxford: Archaeopress, 2004.

BONIFAY, Michel. Observations sur la diffusion des céramiques africaines en Méditerranée orientale durant l'Antiquité tardive. In : BARATTE (F.) et al. (ed.) Mélanges Jean-Pierre Sodini (Travaux et Mémoires, 15). Paris: Collège de France, 2005a: 565-581.

BONIFAY, Michel. In: CHRZANOVSKI, Laurent (Dir.) Lychnological Acts 1. Actes du 1erCongrès international d'études sur le luminaire antique. Nyon Genève, 29. IX - 4.X.2003. montagnac: éditions monique mergoil, 2005b: 31-38 e pl. 12-16.

BONIFAY, Michel. Ceramic Production in Africa During Late Antiquity: Continuity and Change. In: LAVAN, Luke; ZANINI, Enrico e SARANTIS, Alexander (eds.) Technology in Transition A.D. 300-650. Leiden, Boston: Brill, 2007: 143-158. 
BONIFAY, Michel. Production et diffusion des céramiques africaines durant l'antiquité tardive. In: ATTOUI, Redha (ed.) When did Antiquity end? Archaeological case studies in three continents. The Proceedings of an International Seminar held at the University of Trento on April 29-30, 2005 on Late Antique Societies, Religion, Pottery and Trade in Germania, Northern Africa, Greece and Asia Minor. Oxford: BAR International Series, 2011: 15-30.

BONIFAY, Michel. Africa: Patterns of Consumption in Coastal Regions Versus Inland Regions. The Ceramic Evidence (300-700 A.D.). In: LAVAN, L. (ed.) Local Economies? Production and Exchange of Inland Regions in Late Antiquity. (Late Antique Archaeology 10) Leiden: Koninklijke Brill NV, 2013: 529-566.

BONIFAY, Michel. Céramique africaine et imitations: où, quand, pourquoi? In: MORAIS, R.; FERNANDEZ, A.; SOUSA, M.J. (eds.) As Produções Cerâmicas de Imitação na Hispania. Monografias Ex Officina Hispana II, Tomo I, 2014: 75-91.

BONIFAY, Michel; CAPELLI, Claudio, avec la collaboration de FRANCO, Carmela; LEITCH, Victoria; RICCARDI, Laurent e BERNI MILLET, Piero. Les Thermes du Levant à Leptis Magna: quatre contexts céramiques des IIIe et IVe siècles. In: GRIESHEIMER, Marc; GASCOU, Jacques (eds.) Antiquités Africaines. Paris: CNRS Éditions, 2013: 67-150.

BONIFAY, Michel; TCHERNIA, André. Les réseaux de la céramique africaine (IER-VE siècles). In: KEAY, Simon (ed.) Rome. Portus and the Mediterranean. Archaeological Monographs of The British School at Rome. Rome: The British School at Rome, 2012: 315-333.

CAPELLI, Claudio; BONIFAY, Michel. Archéometrie et Archéologie des Céramiques Africaines: une Approche Pluridisciplinaire, 2 Nouvelles Données sur la Céramique Culinaire et les Amphores. In: POULOPAPADIMITRIOU, Natalia; NODAROU, Eleni; KILIKOGLOU, Vassilis (eds.) LRCW 4. Late Roman Coarse Wares, Cooking Wares and Amphorae in the Mediterranean. Archaeology and archaeometry. The Mediterranean: a market without frontiers. Volume 1. BAR International Series 2616 (I). Oxford: Information Press, 2014: 235-253.

CARANDINI; Andrea; ANSELMO, L.; PAVOLINI, Carlo; SAGUİ, L.; TORTORELLA, S.; TORTORICI, E. Atlante delle forme ceramiche, I, Ceramica fine romana nel Bacino mediterraneo (medio $e$ tardo impero),Enciclopedia dell'arte antica. Roma: Treccani, 1981.

CLAY. T. Carthage et son commerce dans l'Antiquité tardive. In: AFRIQUE DU NORD ANTIQUE ET MÉDIEVALE, SPECTACLES, VIE 
PORTUAIRE, RELIGIONS, Actes $d u$ Ve Colloque international sur l'Histoire et l'Archéologie de l'Afrique du Nord (Avignon, 9-13 avril 1990). Paris, 1992: 349-359. Apud Bonifay 2005a: 576, nota 72.

FENTRESS, L.; FONTANA, S., HITCHNER, B.; PERKINS, P. Accounting for ARS: fineware and sites in Sicily and Africa. In: ALCOCK, Susan;. Cherry. J. (eds.) Side by Side Survey. Comparative Regional Studies in the Mediterranean World: 147-62. Oxford: Oxbow, 2004. Apud Bonifay e Tchernia, 2012: 238

HAYES, John W. Late Roman Pottery. London: British School at Rome, 1972. Apud Barbera e Petriaggi, 1993: 8.

MACKENSEN. Michael. Die spätantiken Sigillata - und Lampentöpfereien von el Mahrine (Nordtunisien): Studien zur nordafrikanischen Feinkeramik des 4. Bis 7. Jahrhunderts / mit ein Beitrag von Sebastian Stortz. München: C.H. Beck'sche Verlagsbuchhandlung, 1985. Apud Barbera e Petriaggi, 1993: 425.

PANELLA, Clementina. Merci e scambi nel Mediterraneo tardoantico. In: Storia di Roma III, 2. Turim: Einaudi, 1993: 614-697. Apud Bonifay 2005a: 576 , nota 72 .

PAVOLINI, Carlo. Introduzione. In: BARBERA, Mariarosaria; PETRIAGGI, Roberto Museo Nazionale Romano - Le Lucerne Tard-Antiche di produzione Africana. Roma: Istituto Poligrafico e Zecca dello Stato, 1993: 19.

ZANINI, E. Ricontando la terra sigillata africana. Archeologia Medievale.Siena: Università degli Studi di Siena - Dipartimento di Archeologia e Storia delle Arti, 23, 1996, 677-688. Apud Bonifay e Tchernia, 2012: 328. 